\title{
Information \& Analytical Support of Archetypal Methodology Application for Research of Identity Dynamics of Public Servants of Ukraine
}

\author{
EDUARD AFONIN ${ }^{1}$, TETIANA NOVACHENKO ${ }^{2}$, ANDRII MARTYNOV ${ }^{3}$, SERHII TELESHUN ${ }^{4}$, \\ VITALIY OMELYANENKO ${ }^{5}$ \\ 1,2,4 Department of Public Policy and Political Analytics, NATIONAL ACADEMY FOR PUBLIC ADMINISTRATION \\ UNDER THE PRESIDENT OF UKRAINE, UKRAINE. \\ ${ }^{3}$ Department of History of International Relations and Foreign Policy of Ukraine, INSTITUTE OF HISTORY OF \\ UKRAINE, NATIONAL ACADEMY OF SCIENCES OF UKRAINE, UKRAINE. \\ ${ }^{5}$ Institute of Industrial Economics, NATIONAL ACADEMY OF SCIENCES OF UKRAINE; SUMY STATE PEDAGOGICAL \\ UNIVERSITY NAMED AFTER A.S. MAKARENKO, UKRAINE. E-mail: omvitaliy@gmail.com
}

\begin{abstract}
In the article the results of the analysis of the transformational dynamics of the identity of public servants in Ukraine in the context of the archetypal methodology are presented. The article is based on the ideas of Swiss psychologist Carl Jung on the archetypes of the collective unconscious, the works of Austrian psychologist Sigmund Freud, English historian Arnold Toynbee and the American psychologist Erich Erickson. At the same time, the toolkit of the author's archetypal methodology was used, including the analytical-synthetic model of the "universal epochal cycle» and the psychodiagnostic methodology «BAD». The article substantiates the application of archetypal methodology to establish, through psychosocial differences, the dynamics of the process of identification of public servants of Ukraine within the framework of the socio-historical cycle "Modern-Postmodern». A retrospective historical analysis using the author's analytical and synthetic model of "universal epochal cycle» and the psychodiagnostic methodology "BAD» made it possible to identify the framework of the socio-historical cycle "Modern-Postmodern» in Ukraine, which consists of two normatively stable historical periods - involution / evolution and two transitional states - revolution / co-evolution. The psychosocial characteristics of Ukrainian society and public service as a social institution within the sociohistorical epochs of «Modern» and "Postmodern» were established. The author's archetypal methodology in monitoring studies of the public service of Ukraine made it possible to reveal in the new postmodern conditions a tendency towards the dominance in its public administration of the social modus of identity, which is the guarantor of morality in the national policy and public administration of Ukraine.
\end{abstract}

Keywords: authority, archetypal methodology, social identity, public servants

JEL Classification: H80, L84, E29 


\section{Introduction.}

The starting point of research is the well-known theory of the German sociologist Max Weber about the ideal types of authority (power) - traditional, legal-rational and charismatic - which are provided by different methods of public administration. At the same time, M. Weber, who correlated himself with the Marxist tradition and applied the principle of historicism, considered public-power relations "in a linear perspective» and therefore abstracted himself from the manifestations of nonlinearity, historical dynamics and transformation of social norms, values and identities.

The archetypal approach proposed by the authors within the framework of the cyclical paradigm is counterversion to the principle of linearity. It is based on the analytical-synthetic model of the "universal epochal cycle» (Afonin, 1996; Afonin, 2008) and the personal questionnaire "BAD» (Leonid Burlachuk, Eduard Afonin, Elena Donchenko, 2002), developed on the basis of Jung's six psychosocial opposition scales and adapted to public opinion polls. Using these tools, the authors monitored the dynamics of the identities of public servants in Ukraine $(2005,2009,2014,2019)$. The results obtained are analyzed in the context of the socio-historical periods «Modern» and «Postmodern».

The application of the author's archetypal methodology and tools expands the interdisciplinary advantages of scientific research and opens up resource opportunities for the construction of social reality, including in the public service system of Ukraine.

Therefore the research deals with the application of archetypal methodology to establish, through psychosocial differences, the dynamics of the process of identification of public servants of Ukraine within the framework of the socio-historical cycle «Modern-Postmodern».

The concept of "archetype» (collective unconscious) is interpreted in literature as a prototype, a model for subsequent formations, a generalized characteristic experience of previous generations, which manifests itself in universal models of unconscious mental activity that spontaneously determine human thinking and behavior (The latest philosophical dictionary. Archetype).

As you know, the term "archetype» was introduced into scientific use (1919) by C. Jung. He defined it as an image of a person or a phenomenon that, in the process of socio-historical development, is repeated where the creative imagination of a person is manifested (Jung, 1996). Thanks to the archetype, the integrity of the reproduced identity is preserved - the content that cannot be controlled by the individual will, but can be activated in a large social group (Jung, 2001). This idea of K. Jung echoes the idea of A. Toynbee, a supporter of the concept of "historical circulation", that the subject of human history is a separate civilization that goes through the stages of formation, development and stagnation. In the context of this idea, the role of the "creative minority" is actualized, which, as the scientist notes, is the bearer of any form of social consciousness (Toynbee, 1988). At the same time, we note that the meanings that A. Toynbee applied to the category of «creative minority» correlate with the professional and personal qualities of politicians and public service leaders, correlating with their societal identity mode (Toynbee, 1988).

Recall that the phenomenon of identity as a personal construct has been known since the 17th century, but the first understanding of its essence is associated with the name of the English lawyer and historian of law Henry Maine, which was developed by subsequent generations of scientists (Bauman, 2008). At the same time, both the differentiation of the concepts of «identity" and «identification» and their identity are produced. For example, Z. Freud in his scientific research did not use the term «identity», replacing it with the term «identification» (lat. Identifico - identification equating), which is interpreted as the process of recognition by a system or a person of the opposite system or object (Zaretsky, 2008). According to E. Zaretsky, identification is the main means of forming groups, which Z. Freud defined as a set of individuals who put another system in the place of their ego ideal, which allows one to identify with each other.

Undoubtedly, identification plays an important role in understanding the significance of the other, to whom the person compares himself, no matter in a positive or negative perspective. However, the 
interpretation of the concept of «identity» by the American psychologist E. Erickson significantly expands the content of this category. In particular, he considered the category "identity" in the context of the continuity of self-development of the individual and his ability to maintain internal balance and stable interaction with society. The researcher notes that society influences individuals by providing various resources, material and intangible: religion, economics and politics, with the help of which they can solve the problems of their internal development (Erikson, 1956). At the same time, as the British sociologist G. Giddens noted, first, society forms the identity of an individual through social institutions, and only then, the latter change the dominant values under the pressure of the actions of personal identities (Giddens, 1991). At the same time, according to the British sociologist E. Smith, certain associations / communities cannot be reduced to a simple set of individuals with common features or place of residence. Much more of these collective identities are contained in common values and rules, memory and symbols (Smith, 1994). Identities are "rooted» in dominant social institutions such as language, culture, morality, jurisprudence, race, nation, but identity as a process is characterized by an orientation towards the individuality of a person (Yakubina, 2012).

So, identity is a structure that develops in accordance with the influence of factors both internal (subjective, mental, which determine the attitude of the individual to the world) and external (active interaction with society and its values). We use the concept of «identity», understanding its structure as consisting of two levels - the individual, which characterizes the personal qualities of a person and the social, which is the result of identifying the individual with the expectations of the norms of his social environment.

The important thing is that it is impossible to separate these two levels of identity, interpreting the personal aspect as internal and the social aspect as external. The personality's ideas about itself are perceived by it as their own, inseparable from its "self» - the archetype of the mental integrity of the personality, which is the result of the interpretation of social norms. At the same time, a person's personal norms may not coincide with the norms and roles that are accepted by him during social interaction. Therefore, the personal «|» is affirmed by achieving parity between the individual and social aspects of identity.

Thus, identity is not inherent in an individual from birth, since the dynamics of its genesis occurs during social interaction and can only be determined by individuals, because only they, possessing subjectivity, are capable of attributing / not attributing certain meanings to themselves.

\section{Research methods and models.}

The use of archetypal methodology, which is characterized by the interdisciplinary context of scientific dialogue, makes it possible to move towards understanding the process of changes in the psychosocial properties of public servants, which, reflected in the modes of identity, form the types of their authority (from the latin «Auctoritas» - power, influence, force, which in turn formed from "auctor» - creator, inventor, protector, advisor). As you can see, the concept of «authority» contains two concepts of power - test-based and personalistic, which are test-related to the personal nature of power; in other words, there is no impersonal power. This embodies the fact, fundamental in its significance, that a specific personality of a public servant, representing public authorities, interacts with other representatives of the community and influences the acceptance / rejection of his personality as authoritative.

At the same time, in the well-known theory of M. Weber, three ideal types of authority (power) are distinguished, which are provided by various methods of management, namely:

traditional authority - based on belief in the sacredness of traditions and the perception of those who govern as bearers of this tradition;

legal-rational authority - based on submission to formal rules, which are carried by the leader / ruler, faith (trust) in their legality; 
charismatic authority - based on belief in the extraordinary qualities of a leader / leader, exceptional dedication and unconditional execution of his orders and the rules imposed by him (Weber).

In M. Weber's theory, the categories "authority» on the one hand, and «power», «influence», "personality» on the other hand, are correlated. Scientists also proclaim the principle of historicism, according to which the substantial variability of social problems entails the variability of "exemplary» actions. This principle is embodied in the understanding of power relations mediated by ideal types of authority (power). At the same time, the observed linearity of the proposed perception abstracts the researcher from the possible multiplicity and nonlinearity of possible relationships.

A certain opposition of linearity in understanding the socio-historical process and its phenomena is the author's analytical and synthetic model of the "universal epochal cycle» (Afonin, 1996; Afonin, 2008), in which scientists argue that the historical development of society as a national-state entity and a subject of civilization is carried out within the framework of the implementation of epochal cycles, as a set of interrelated historical, political, economic and socio-psychological processes and phenomena. Any society, like a separate individual who is its "creator», lives 5 universal epochal cycles, each of which has a long history, forms a cycle, is characterized by similarity, consistency, integrity and represents a unit of socio-historical analysis (Afonin, 2008).

In accordance with the Hegelian dialectical law of denial of negation and similar to naturalscientific models of cyclical development, the structure of the "universal epochal cycle» is made up of: two normalized contraversion periods - involution / evolution with their inherent static and dynamic social norms, and two transitional contraversion states - revolution / coevolution, which give rise to respectively, collective and individual social subjects and the corresponding institutional changes. The historical logic of the embodiment of the universal epochal cycle is the sequence: revolution - involution - coevolution - evolution.

A revolution is a transitional state of social development, giving birth to a collective subject «We». The state, when the result of the previous experience is generalized, the choice of new social and value orientations is carried out, new institutions are born and the prerequisites for the further socio-historical development of the community are laid.

Involution is a period in the history of society in which the social order is determined by a static norm and functioning prevails over the development of the social system. Accordingly, the social space is curtailed and the social structure is simplified. Society is "closed" in nature, dominated by state institutions that maintain social stability, solidarity and unity. The degree of individual freedom in such society is limited by collectivist morality, which sets before him socially important goals and interests. The "emotional-sensual» typology of a person, focused on all-round development, fundamental education, general social values and state control, prevails. The homogeneous nature of society is cultivated, the assimilation and use of social and material symbols, including power. The difference between ordinary people and civil servants, who turn into the nomenclature, is leveled. At the same time, this does not contradict the development of the cult of leaders and geniuses.

Co-evolution is a transitional state of social development, giving rise to an individual, rational and self-sufficient subject «|» with characteristic humanistic values and anthropocentric orientation in social relations, the inherent mission of driving subsequent modernization changes, expanding social space and "openness» of society.

The transitional process is accompanied by the "erosion» of former, static in nature, social norm (anomie), and in its final phase - a break in the relationship between the political, economic and cultural subsystems of society. The latter is accompanied by a pathopsychological state "psychoneurosis of delayed action» (according to Blume Zeigarnik) and authoritarian political intentions.

Evolution is a period in the history of society, the social order in which is determined by a stable, dynamic in nature social norm, which determines the predominance of development over the functioning of the social system. Innovation becomes a driver of development, and communication 
Information \& Analytical Support of Archetypal Methodology Application for Research of Identity Dynamics of Public Servants of Ukraine

becomes a harmonizing factor. The homogeneity (homogeneity) inherent in involution is transformed in evolutionary development into heterogeneity (heterogeneity), and "closeness» - into «openness» of social system.

Social equilibrium is maintained by the progressive achievements of the rational (emancipated) individual, whose psychological structure is determined by the cognitive component. Dominated by the "rational» typology of a person focused on personal development and self-realization, lifelong education, individual values and self-control (Great co-evolution).

The model of the "universal epochal cycle» is supplemented by monitoring studies (2002-2020) using the author's psychodiagnostic methodology «BAD» (Burlachuk, Afonin, Donchenko, 2002), which determines personal and social changes using six psychosocial opposition scales: extraversion / introversion; emotionality / pragmatism; irrationality / rationality; intuitiveness / sensibility; externality / internality; executability / intentionality (Afonin, Martynov, 2019).

\section{Results and discussion.}

The analysis of the dynamics of the identity of public servants in Ukraine was carried out within the framework of the socio-historical cycle Modern-Postmodern. In particular, according to analytical-synthetic model of "universal epochal cycle» the Soviet period (the Modern period) is described as involution with its inherent features: the homogeneity of the vision of the world in which social plurality is reduced to social-class universality; confidence in the power of human progress is embodied in the superiority of the future over the past and present. The basis of selfawareness in society is formed by the modus of social identity, which creates the group phenomenon «We».

Society is characterized by the traditional type of authority of power with inherent in the overwhelming majority, including civil servants, such psychosocial properties as: extraversion is a feature of the psyche, focused on the external, material forms of objects and things and, accordingly, on material resources and values of the surrounding world, forming appropriate norms of behavior and attitude; emotionality - the ability of a person to interact with others based on emotions and make management decisions with a feeling of empathy (sympathy or antipathy) for another; irrationality - the predominance of the kinetic and visual system of perception, the implementation of activities without prior preparation and setting on another person, the tendency to start many things at the same time, but not all of them to complete; intuitiveness - a tendency: to live in the future, into which the experience of the past is brought in (extrapolation), indecision and doubt; in science and education, the predominance of theory rather than practice; externality - a tendency to interpret current events as dependence on external forces; disclaiming responsibility for results, unfulfilled plans; execution - moderation in action, the real advantage of consumption over creation, naivety, the need for a strong and strong-willed ally (Novachenko, Afonin, 2019).

The Postmodern that is replacing the Modern is changing the homogeneous nature of society into a heterogeneous one with its inherent implosive, explosive "triumph" of individuality, awareness of personal responsibility for the processes taking place in society and the state. The self-sufficient individual who is affirming in the historical arena and the phenomenon of "I" is now generated by a new - societal mode of identity (Afonin, 2010). The latter, like its predecessor, is a social mode of identity (Afonin, 2010), characterized by integrity. True, among the inherited elements of the social and psychological, socially ideal and symbolic, intangible values play a decisive role in its formation. The perception and understanding of a modern person, including a state person, or rather, a public servant, is significantly influenced by socio-political reality, which motivates the behavior of employees in the field of public administration.

The outlined period is characterized by a legal-rational type of authority, which is actively replacing the charismatic authority of a public servant, which temporarily dominated in the transitional period of social development (co-evolution). For these types of authority of public servants, the dominant properties are: introversion, which is characterized by active, personally 
responsible behavior of a public servant, values of self-realization; pragmatism, which focuses on functional and competence-based consistency, the rule of law and abstraction from emotional assessments; such a public servant can be convinced only with weighty logical arguments; rationality, which predetermines the orientation of a public servant to the auditory and visual systems of information perception, what is subject to rational and logical explanation, resistance to stress factors and stable performance; sensibility, which correlates with the practicality of a public servant, his activity and a realistic assessment of facts and events; internality, which is characterized by a tendency to evaluate all significant events as a result of their own activities; intentionality, which characterizes a public servant as a strong, proactive, decisive and self-confident, and at the same time tolerant person with high intelligence. Such a public servant is emotionally stable, with a high level of self-control and adequate self-esteem.

At the same time, monitoring studies of the Ukrainian school of archetypics indicate radical and nonlinear in nature changes that the psychosocial nature (Table 1) and identity (Table 2) of public servants in Ukraine undergoes in the course of social transformation.

In particular, the analysis of the monitoring data revealed an objective tendency of "stratification» of the previously monolithic and homogeneous psychosocial structure of the public service institution into two psychosocial groups of different quality - leaders and specialists. Moreover, if the psychosocial properties of the first group (leaders) are predetermined by the societal mode of identity, then the second group (specialists) is determined by the social mode of identity.

At the same time, the qualitative characteristics of the integral institution of public service will color the mode of a larger social group, a group of specialists, namely: the social mode of identity.

Table 1. Dynamics of societal changes in the public service system of Ukraine

\begin{tabular}{|c|c|c|c|c|}
\hline \multirow[b]{2}{*}{ Psychosocial properties } & \multicolumn{4}{|c|}{ Public servants } \\
\hline & $\begin{array}{c}05.2005 \\
N=439\end{array}$ & $\begin{array}{c}04.2009 \\
N=623\end{array}$ & $\begin{array}{c}11.2014 \\
N=821\end{array}$ & $\begin{array}{l}10.2019 \\
N=6335\end{array}$ \\
\hline Extroversion & 41,5 & 45,1 & 29,7 & 37,8 \\
\hline Introversion & 18,2 & 9,0 & 14,8 & 10,4 \\
\hline Ambivalence & 45,3 & 45,9 & 55,4 & 51,8 \\
\hline Emotionality & 14,1 & 20,0 & 22,5 & 23,3 \\
\hline Pragmatic & 16,4 & 15,4 & 8,4 & 10,3 \\
\hline Ambivalence & 69,2 & 64,5 & 69,3 & 66,4 \\
\hline Irrationality & 0,7 & 5,3 & 6,8 & 3,6 \\
\hline Rationality & 64,9 & 51,5 & 37,8 & 51,6 \\
\hline Ambivalence & 34,4 & 43,2 & 55,4 & 14,8 \\
\hline Intuitiveness & 72,7 & 53,3 & 37,2 & 42,8 \\
\hline Sensory & 6,4 & 4,5 & 9,8 & 9,4 \\
\hline Ambivalence & 20,9 & 42,2 & 53,0 & 18,6 \\
\hline Externality & 8,4 & 8,7 & 13,5 & 13,3 \\
\hline Internality & 47,6 & 25,4 & 19,4 & 16,6 \\
\hline Ambivalence & 44,0 & 66,0 & 67,1 & 70,1 \\
\hline Execution & 2,1 & 4,6 & 6,0 & 3,3 \\
\hline Intentionality & 78,8 & 62,8 & 51,8 & 61,1 \\
\hline Ambivalence & 19,1 & 32,6 & 42,3 & 35,5 \\
\hline
\end{tabular}


Information \& Analytical Support of Archetypal Methodology Application for Research of Identity Dynamics of Public Servants of Ukraine

Table 2. Dynamics of identification processes in public service system of Ukraine

\begin{tabular}{|l|c|c|c|c|}
\hline \multicolumn{1}{|c|}{$\begin{array}{c}\text { Formation state of } \\
\text { property }\end{array}$} & $\begin{array}{c}\mathbf{0 5 . 2 0 0 5} \\
\mathbf{N = 4 3 9}\end{array}$ & $\begin{array}{c}\mathbf{0 4 . 2 0 0 9} \\
\mathbf{N = 6 2 3}\end{array}$ & $\begin{array}{c}\mathbf{1 1 . 2 0 1 4} \\
\mathbf{N = 8 2 1}\end{array}$ & $\begin{array}{c}\mathbf{1 0 . 2 0 1 9} \\
\mathbf{N}=\mathbf{6 3 5 0}\end{array}$ \\
\cline { 2 - 5 } $\begin{array}{l}\text { Modern modus of societal } \\
\text { identity }\end{array}$ & 37,1 & 28,1 & 19,3 & 26,6 \\
\hline $\begin{array}{l}\text { Traditional modus of social } \\
\text { identity }\end{array}$ & 23,3 & 22,8 & 15,0 & 20,6 \\
\hline $\begin{array}{l}\text { Aggregate measure of } \\
\text { identity }\end{array}$ & 60,4 & 50,9 & 34,3 & 47,2 \\
\hline Unformed identity & 39,6 & 49,1 & 65,7 & 52,8 \\
\hline
\end{tabular}

Source: author's research

\section{Conclusion.}

The research carried out by the authors made it possible to substantiate the expediency of archetypal methodology tools application, namely: the analytical-synthetic model of the "universal epoch-making cycle» and the psychosocial methodology of dietary supplements, which gave us the opportunity to determine the configuration of the dynamics of the identity of public servants in the cycle «Modern-Postmodern», which consists from two stable periods (involution / evolution) and two transitional states (revolution / co-evolution).

Application of the "BAD» methodology provided an opportunity to establish the psychosocial characteristics of socio-historical eras of the Modern-Postmodern cycle. For the Modern era (involutionary period), the characteristic psychosocial features are: extraversion, intuition, emotionality, externality, execution and irrationality; for the postmodern era (evolutionary period) are inherent: introversion, sensory, pragmatic, internality, intentionality, rationality. In the context of the involutionary and evolutionary periods, there is a change in the modes of identity - from social to societal.

Monitoring studies of Ukrainian school of archetypics, carried out using the author's psychodiagnostic techniques, convincingly testify to the positive changes that identity modi of public servants undergo in the context of social transformation.

The social identity of a modern society is characterized by linearity with the value predominance of the external - social and material factor, as well as the emotional-sensual (irrational) psychosocial nature of the personality of a public servant. In accordance with this, the traditional type of authority (power) is established.

In postmodern society, the semantic structure of plurality is manifested, the internal psychosocial factor is actualized, and there is also an opportunity for public servants to acquire a societal identity, with a rational abstract-logical nature, which confirms the archetype of self-creation and selfrealization. Most dynamically, as the monitoring of societal changes and identification processes in the institution of public service shows, the new properties and modus of identity were dominated by the leaders, which greatly contributed to the development of corruption.

At the same time, as the social transformation processes in Ukraine deepened, its public service institute began to "stratify" into a complex heterogeneous formation - a management team and a staff of specialists with appropriate societal and social modes of identity. The new - heterogeneous structure of the institution of public service in Ukraine promotes the return of morality to politics and management, the organization of professional activities by public servants in accordance with public interests and needs, asserting a legal-rational and charismatic type of authority (power). 


\section{References}

1. Afonin E. A. (1996). Development of Ukraine: Macrosocial Pidhid. Viche, 1, 45-55.

2. Afonin E. A. (2008). Social Cycles: Historical and Sociological Approach. Kharkiv: View «Gold Mile».

3. Afonin E., Martynov A. (2019). Ukrainian miracle: From Depression to Social Optimism. Kyiv: KyivMohyla Academy Publishing House.

4. Afonin E.A. (2010). Human identity and features of its influence on politics and public administration. Conceptual bases of interaction of policy and management: textbook. Nat. Academy of Public Administration under the President of Ukraine. Kyiv: NAPA. [online] Available at: http://lib.rada.gov.ua/static/about/text/Konzept_zasadi.pdf [Accessed 03 January 2021].

5. Bauman Z. (2008). In search of a holding center. Global Modernities / ed. M. Featherstone, S. Lesch, R. Robertson. Kyiv: Nika-Center.

6. Erikson E. (1956). The problem of ego identity. Journal of the American Psychkanalytic Association, 4, 56-121.

7. Giddens A. (1991). Modernity and self-identity: Self and society in the Late Modern Age. Cambridge: Polity Press.

8. Great co-evolution: Global problems of contemporaneity: historic-sociological analysis / E. A. Afonin, O. M. Bandurka, A. Y. Martynov. Kyiv: Parliamentary Publishing House, 2003. [online] Available at: http://lib.rada.gov.ua/static/LIBRARY/povni_text/coev_eng.pdf [Accessed 03 January 2021].

9. Jung K.G. (1996). Man and his symbols. St. Petersburg.

10.Jung K.G. (2001). Psychology of the unconscious. Moscow: Canon.

11.Novachenko T.V., Afonin E.A. (2019). Authority of the head in public administration: textbook. Kyiv: NAPA.

12.Smith E.D. (1994). National identity. Kyiv: Osnovy.

13.The latest philosophical dictionary. Archetype. [online] Available at: https://gufo.me/dict/philosophy/\%D0\%90\%D0\%A0\%D0\%A5\%D0\%95\%D0\%A2\%D0\%98\%D0\%9F [Accessed 03 January 2021].

14.Toynbee A. (1988). Philosophy of culture. Formation and development. St. Petersburg: Lan.

15.Weber M. Types of domination. [online] Available at:

http://www.gumer.info/bibliotek_Buks/Sociolog/veber/tip_gosp.php [Accessed 03 January 2021].

16.Yakubina V.L. (2012). Current situations with identity and identifications: methodological conceptualization of registers. Almanac. Philosophical problems of the humanities, 21, 66-69.

17.Zaretsky E. (2008). The birth of identical politics. 1960s: psychoanalysis and the division into public and private. Global Modernities / ed. M. Featherstone, S. Lesch, R. Robertson. Kyiv: Nika-Center. 